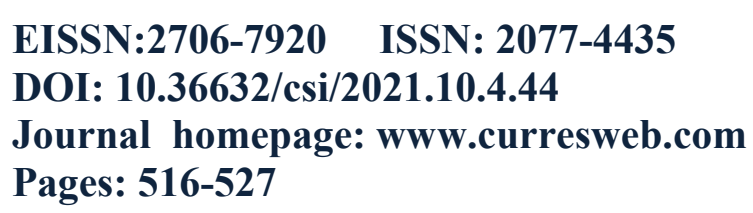

\title{
Influence of Using Date Pits and Stevia Leaves Powder on Rats Suffering from Diabetic
}

\author{
Mona S. Halaby ${ }^{1}$ and Mena M. Hanna ${ }^{2}$
}

${ }^{I}$ Nutrition and Food Sci. Dept., Faculty of Home Economics, Helwan Univ., Cairo, Egypt. ${ }^{2}$ Food Technologist, Design Engineer, IKEA of Sweden.

Received: 20 Sept. $2021 \quad$ Accepted: 21 Oct. $2021 \quad$ Published: 30 Oct. 2021

\begin{abstract}
The present work was conducted to evaluate the effect of feeding diabetic rats on different levels of Date pits powder (DPP) and Stevia leaves powder (SLP) on the chemical constituents, the nutritional value and blood parameters in experimental rats through biological evaluation. Thirty five male albino rats were divided into five groups ( 7 rats of each) and fed on diets for 8 weeks. The first group was fed on basal diet as a (negative control group). The second group was injected with alloxan to induce hyperglycemia (positive control group) then feed on basal diet. The other three groups after being injected with alloxan were received basal diets fortified with (5\% Date pits powder $+0.7 \%$ Stevia or $10 \%$ Date pits powder $+0.7 \%$ Stevia and $15 \%$ Date pits powder $+0.7 \%$ Stevia) respectively. At the end of the experimental period rats were sacrificed, blood samples were collected from the aorta then separate serum to determine glucose, insulin, HbAlc, total cholesterol and other lipid, and also to determine each of liver and kidney functions. Our results showed significant reduction in the glucose, HbAlc, TC, TG, LDL-C and VLDL-C, as well as reducing hazards on liver and kidney functions compared with positive control group. So SLP and DPP fortified diet is recommended to gain healthy benefit to decrease the risk of diabetic disease.
\end{abstract}

Keywords: Diabetes, Albino rats, Stevia leaves, Date pits, Lipid profile, Liver \& kidney functions.

\section{Introduction}

Type 2 diabetes mellitus (DM) is probably one of the oldest diseases known to man. It was first reported in Egyptian manuscript about 3000 years ago. Type 2 DM was described as a component of metabolic syndrome (Baynest, 2015). DM has become a global epidemic in the recent decades; it's associated with relatively specific long term micro vascular complications affecting the eyes, kidneys and nerves, as well as a major risk factor for cardiovascular disease a leading cause of blindness, nontraumatic amputation and end-stage renal disease. Diabetes is a disease of worldwide significance and increasing their prevalence without any plateau (Punthakee et al., (2018).

Globally, the prevalence of diabetes was estimated and the latest statistical data of the International Diabetes Federation (IDF) showed that at least 415 million adults worldwide were living with diabetes, and by 2045 this will rise to 700 million compared with 382 million cases in 2013 . Moreover, IDF showed that there are 5.1 million deaths caused by this disease per year. The expense for the treatment of diabetes is high according to Xing et al. (2015) and Zheng et al. (2018). The experts agreed that in both type 1 and type 2 diabetes, various genetic and environmental factors can result in the progressive loss of $\beta$-cell mass and/or function that manifests clinically as hyperglycemia. Once hyperglycemia occurs, patients with all forms of diabetes are at risk for developing the same complications, although rates of progression may differ revealed by American Diabetes Association, (2018).

However, non-nutritive sweeteners have been utilized in the diet of diabetic patients as an agent to replace glucose and sucrose. Since saccharin might be removed from the marketplace. In fact, dry leaves of Stevia rebaudiana is a small herbaceous, it is grown all across the world. It's a natural sweetener plant known as "Sweet Weed", "Sweet Leaf", "Sweet Herbs" and "Honey Leaf". Stevia is 
a calorie-free and 300 times sweeter than sugar-cane. Stevia for last few years has been seen as healthy replacement of sugar; it contains phyto-chemical compound that helps to cure blood sugar, cholesterol and blood pressure especially for those people who are suffering from metabolic disorders or want to maintain healthy (Jitendra et al., 2012; Gupta et al., 2013 and Singh et al., 2021).

Date pits, also called pips, stones or seeds are by-products, which used in complementary and alternative medicine in an effort to prevent illness, reduces stress, or control disease showed by Sabah et al. (2010). Chemical and nutritional constituents of date pits has been reported as containing 5-10\% moisture, $10-20 \%$ crude fiber, and $1-2 \%$ ash, with high amounts of carbohydrates $(75-80 \%)$, fat (10$12 \%$ ) and proteins (5-6\%) (Mobarak, 2009). Moreover, pits contain high levels of phenolics (3102$4430 \mathrm{mg}$ Gallic acid $1100 \mathrm{mg}$ ); it is considered as an important source to increase the antioxidant intake in the human diet by enriching food with phenolics mentioned by Ardekani et al. (2010) and Amany et al. (2012). Date pits, could be regarded as an excellent source of food ingredients with interesting technological functionality that could also be used in food as an important source of dietary fiber (Bouaziz et al., 2010; Halaby et al., 2014 and Shehzad et al., 2021).

Few researches have been published regarding incorporation of Stevia and Date pits with the diet with higher degree of acceptability. In fact, nutrition is an essential element of treatment and maintenance of blood sugar homeostasis. There is an increasing demand for healthy food products, natural and high quality, among consumers. Therefore, one recent trend is to enrich the components in food products to overcome health problems and many of them are known to be effective against diabetes.

The aim of current study is to find the effect of different doses of Date pits powder with Stevia leaves powder and supplemented with the diet on the metabolic control of diabetes through biological evaluations to increasing interest in the use of medicinal plants as a functional foods and natural antioxidant or as food additive.

\section{Materials and Methods}

\subsection{Materials}

Date Pits powder (Semi- dry) and Stevia leaf powder (rebaudiana) were obtained from Field Crops Research Institute of the Agricultural Research Centre, Cairo, Egypt. Casein, Cellulose, Vitamins, Minerals and Choline chloride were obtained from El-Gomhorya Pharmaceutical Company Cairo, Egypt. Corn oil and starch were purchased from the local market. Thirty five adult male albino rats (Sprague Dawley strain) weighting an average $(150-180 \mathrm{~g})$ were obtained from the laboratory animal colony of Vacsera Helwan, Egypt. Kits used to determine serum cholesterol, triglycerides, LDL, uric acid, urea nitrogen, creatinine and transaminases produced by Egyptian American Company for laboratory service and supplied by Alkan Company.

\subsection{Methods}

\section{Chemical Constituents of Raw Materials}

Moisture, protein, ash, total fiber, fat and tannins content were determined according to the method outlined in A.O.A.C. (2007). Total carbohydrates were determined by difference as mentioned by Abd El-Latif (1990). Lignin content was measured according to the method described by Tanaka et al. (1985). Cellulose and hemicelluloses contents were determined as described by Chahal et al. (1979). Glycosides compounds from Stevia rebaudiana were analyzed using HPLC described by Kolb et al. (2001). Mineral contents including ( $\mathrm{Na}, \mathrm{K}, \mathrm{Ca}, \mathrm{Fe}, \mathrm{Zn}, \mathrm{Mg}$ and $\mathrm{P}$ ) were determined according to the method described by A.O.A.C. (2005) using atomic absorption Spectrophotometer. Vitamins including $\left(\mathrm{B}_{1}, \mathrm{~B}_{2}, \mathrm{~B}_{6}, \mathrm{C}\right.$, Folic acid and Niacin) were assayed as recommended by Chrom, (1999 \& 2006). Saturated and Unsaturated fatty acids were determined by "Hydrolytic Extraction Gas Chromatographic" according to the method described by ISO 5508 (1990) \& ISO 5509 (2000).

\section{Diet composition}

The basal diet was prepared according to Reeves et al. (1993). The vitamin mixture was prepared according to Kanapka \& kleinberg (1983) and mineral mixture was prepared according to Hegested et al. (1941). 


\section{Experimental design}

Male rats were adapted and fed on the basal diet for two weeks prior to commencement of the experiment, housed in well aerated cages under hygienic condition and water was introduced adlibitum, in the animal house at Faculty of Home Economics, Helwan University. After this week, rats were divided into 5 main groups ( 7 rats of each) and fed on diets for eight weeks as follows: The first group was fed on basal diet as a (negative control group). The second group was injected with alloxan to induce hyperglycemia (positive control group) then feed on basal diet.

The other three groups after being injected with alloxan were received basal diets fortified with Date pits powder (DPP) at various ratios $(5,10 \& 15 \%)$ and Stevia leaves powder (SLP) at $0.7 \%$ for 8 weeks respectively. During the experiment period the quantities of diet, which were consumed and / or wasted, were recorded every day. In addition, rat's weight was recorded weekly, to determine body weight gain \%, feed intake, and feed efficiency ratio according to Chapman et al. (1959).

\section{Blood Sampling}

At the end of the experiment period the rats were fasted over night before sacrificing. Blood samples were collected from the aorta. They were centrifuged for 15 minutes at $3000 \mathrm{rpm}$ to separate the serum. The serum was carefully separated into dry clean Wassermann tubes by using a Pasteur pipette and kept frozen till analysis at $-20^{\circ} \mathrm{C}$.

\section{Biochemical analysis of serum}

Glucose (Trinder, 1959), insulin (Burgi et al., 1988), HbA1c Sudhakar \& Pattabiraman (1981), total cholesterol (Allain et al., 1974), triglycerides (Fassati \& Prencipe 1982), HDL-C (Lopes et al., 1977), LDL-C and VLDL-C were calculated by using the method of Friedewald et al., (1972). Uric acid, urea nitrogen and creatinine were estimated according to the methods described by Fossati et al., (1980), Patton \& Crouch, (1977) and Bartels et al., (1972) respectively. AST and ALT were determined according to Retiman \& Frankel, (1957).

\subsection{Statistical Analysis}

Results were analyzed according to SPSS program (version 20). ANOVA test was used to compare results among groups and $\mathrm{P}<0.05$ was considered to be significant according to Armitage \& Berry, (1987).

\section{Results and Discussion}

\subsection{Chemical constituents of raw materials}

Stevia leaves and Date pits powder were investigated on dry weight basis. The following parameters in Tables (1) were pointed out for moisture, protein, ash, fat, carbohydrate, total fibre, lignin, cellulose, hemicellulose, and tannine, the ratios were (5.03 - 4.28), (6.29 - 5.79), (4.01 - 1.09), $(2.57$ - 10.13), (64.84 - 14.47), (17.26 - 64.24), (5.35 - 13.67), (9.18 - 36.32), (2.73 - 14.25) (g/100g DW) and (5.67-2.74mg/100g DW), respectively. The present results agreement with Gasmalla et al. (2014) they noticed that the tannin content of Stevia leaves ranged from $5.2-6.0 \%$, and there is no significant difference between the three drying methods (microwave, sun and oven drying). However, these data are more or less in accordance with those reported by Yadav \& Guleria, (2012) and Gutierrez, (2013).

Table 1: Chemical constituents of Stevia leave and date pits powder (g/100g dry weight basis)

\begin{tabular}{cccccc}
\hline Component (\%) & SIP & DPP & Component (\%) & SIP & DPP \\
\hline Moisture & 5.03 & 4.28 & Total fiber & 17.26 & 64.24 \\
Protein & 6.29 & 5.79 & Lignin & 5.35 & 13.67 \\
Ash & 4.01 & 1.09 & Cellulose & 9.18 & 36.32 \\
Fat & 2.57 & 10.13 & Hemicellulose & 2.73 & 14.25 \\
Carbohydrate & 64.84 & 14.47 & Tannins & 5.67 & 2.74 \\
\hline
\end{tabular}

SIP: Stevia leave powder DPP: Date pits powder. 
From Table (1) results it could be noticed that higher moisture, protein, ash, carbohydrate and tannin contents were that of the SLP than that of DPP (5.03, 6.29, 4.01, 64.84 and 5.67\% DW). While, results of fat, total fibre, lignin, cellulose and hemicelluloses contents in DPP had the highest values than that of SLP $(10.13,64.24,13.67,36.32$ and $14.25 \%$ DW) respectively. The present results are in agreement with those Ardekani et al. (2010); Najafi (2011) and El-Porai et al. (2013). They published that the date seeds contain high levels of dietary fiber $(78-80 \mathrm{~g} / 100 \mathrm{~g})$, and the insoluble dietary fiber in date seeds are those components that are insoluble in water and includes cellulose, hemicelluloses and lignin confirmed by Amany et al. (2012) and Halaby et al. (2014).

Contents of the sweet glycosides in the SLP are shown in the Table (2) which had the highest contents of Stevioside 7.48\% and rebaudioside A 2.89\% are the two major steviol glycosides from the leaves of Stevia. These glycosides and their derivatives are known to account for $4 \%-20 \%$ of the dry weight of Stevia leaves (Geuns et al., 2003). Recently approved by the US FDA as GRAS (generally recognized as safe), have been widely used as a natural sweetener or a dietary supplement in various food and beverage products (Gasmalla et al., 2014) they published that Stevioside tastes 250-300 times sweeter than sucrose but exhibits a significant bitter aftertaste. Nowadays the extraction of sweeteners from Stevia leaves is a growing industrial and commercial worldwide sector; more than 750 tons of Stevia leaves per year are used as crude extract for consumption and extraction of glycosides (Campos et al., 2014 and Singh et al., 2021).

Table 2: Amount of sweet glycosides in Stevia leaves

\begin{tabular}{ll}
\hline Glycosides Contents (\%) & Amount of sweet glycosides \\
\hline Stevioside & 7.48 \\
Rebaudioside A & 2.89 \\
Rebaudioside C & 1.09 \\
Dulcoside A & 0.56 \\
\hline
\end{tabular}

The following parameters for SLP and DPP were determined for the content of minerals and vitamins including, (Na, K, Ca, Fe, Zn, Mg \& P) and ( $\mathrm{B}_{1}, \mathrm{~B}_{2}, \mathrm{~B}_{6}, \mathrm{C}$, Folic acid \& Niacin). Results in Table (3) indicated that Stevia leaves had the highest contents of all these minerals except Fe, Zn and $\mathrm{Mg}$ comparing with DPP which contained good amounts of $\mathrm{Fe}, \mathrm{Zn}$ and $\mathrm{Mg}$. Moreover, SLP contained good amounts of $\left(B_{2}\right.$ and $\left.C\right)$, the values of vitamins with an average of 0.54 and $15.72(\mathrm{mg} / 100 \mathrm{~g})$ respectively. At the same time SLP and DPP contained high amounts of Folic acid, the ratios reach to 56.34 and $32.95(\mathrm{mg} / 100 \mathrm{~g})$. These results in agreement with the previous authors Gutierrez, (2013) and Campos et al., (2014) they published that Stevia contains important minerals such as calcium, phosphorus, iron, sodium, and potassium. While, Gasmalla et al. (2014) showed that the values of different metals in stevia leaves samples vary according to drying method; also Nandhagopal et al., (2013) and Shehzad et al., (2021) noticed that date seeds considered as a good source of the microelements such as $\mathrm{K}, \mathrm{P}, \mathrm{Ca}$ and $\mathrm{Mg}$.

Table 3: Minerals and vitamins composition of Stevia leaves powder and date pits powder $(\mathrm{mg} / 100 \mathrm{~g}$ dry weight basis)

\begin{tabular}{|l|l|l|l|l|l|}
\hline $\begin{array}{l}\text { Micronutrients } \\
\text { Minerals }\end{array}$ & SIP & DPP & $\begin{array}{l}\text { (Micronutrients) } \\
\text { Vitamins }\end{array}$ & SIP & DPP \\
\hline Sodium (Na) & 90.26 & 02.3 & Vitamin (B1) & 0.02 & 0.04 \\
Potassium (K) & 1385.12 & 143.25 & Vitamin (B2) & 0.54 & 0.02 \\
Calcium (Ca) & 549.65 & 84.80 & Vitamin (B6) & 0.01 & 0.03 \\
Iron (Fe) & 21.49 & 43.10 & Vitamin (C) & 15.72 & --- \\
Zinc (Zn) & 2.09 & 16.82 & Folic acid & 56.34 & 32.05 \\
Magnesium (Mg) & 314.07 & 1857.0 & Niacin & -- & 0.43 \\
Phosphorus (P) & 250.51 & 14.20 & --- & -- & \\
\hline
\end{tabular}


In fact, SLP and DPP have major source of various types of nutrients with promising evidence of health benefits; however, variation in composition may be related to changes in location, or genotype and / or the time of different drying methods.

Types and concentrations of fatty acids extracted from the SLP and DPP using gas chromatography give in Table (4). The results revealed that eight saturated fatty acids were recognized in SLP, besides four unsaturated fatty acids were identified in the same leaves, the most abundant saturated fatty acids in SLP was Palmitic, Stearic and Palmitoleic acids at the ratios (26.51; $3.23 \& 2.38 \mathrm{mg} / 100 \mathrm{~g}$ ), respectively. Linolenic acid was the primary unsaturated fatty acids in SLP with concentration $25.93 \%$, it was followed by Linoleic acid (15.26\%) and Oleic acid $(8.22 \%)$, respectively. SLP proves to be a rich source of linolenic acid, which may contribute to maintain an ideal fatty acid ratio in human diet. These results are in agreement with Mondaca et al. (2012) and Gasmalla et al. (2014). At the same table, showed that eight saturated fatty acids were recognized in DPP beside five unsaturated fatty acids were identified in this variety. These results are in agreement with Walid \& Richard (2003); Akbari et al. (2012) and Halaby et al. (2014). It could be noticed that DPP showed higher unsaturated and saturated fatty acids than that of SLP.

The results given in Table (4) revealed that the most abundant saturated fatty acids in date pits compared with SLP were Ligoceric acid, Docosanoic acid, Arachidic acid, Stearic acid, Margarinic acid Palmitic acid, Myrisitic acid and Lauric acid at the ratios (24.686-0.010; $20.281-0.009 ; 16.864$ $-0.004 ; 13.556-3.23 ; 11.682-0.00 ; 10.181-26.51 ; 7.879-0.001$ and $6.206-0.002 \mathrm{mg} / 100 \mathrm{~g}$ ), respectively.

Table 4: Fatty acids content of Stevia and date pits powder (mg/100g dry weight basis)

\begin{tabular}{lcc}
\hline & \multicolumn{2}{c}{ Material } \\
\cline { 2 - 3 } Fatty acids & SLP & DPP \\
\hline Saturated FA & & \\
Lauric acid C 12:0 & 0.002 & 6.206 \\
Myrisitic acid C 14:0 & 0.001 & 7.879 \\
Palmitic acid C16:0 & 26.51 & 10.181 \\
Palmitoleic acid C16:1 & 2.38 & -- \\
Margarinic acid C 17:0 & --- & 11.682 \\
Stearic acid C 18:0 & 3.23 & 13.556 \\
Arachidic acid C 20:0 & 0.004 & 16.864 \\
Docosanoic acid C22H44O22 & 0.009 & 20.281 \\
Ligoceric acid C24H48024 & 0.010 & 24.686 \\
Unsaturated FA & & \\
Hexadecenoic acid C 16:1 $\mathbf{~ 7}$ & --- & 10.619 \\
Heptadecenoic acid C 17:1 & 0.001 & 12.152 \\
Oleic acid C18:1 $\mathbf{\omega}$ 9 & 8.22 & 14.035 \\
Linoleic acid C 18:2 $\boldsymbol{\omega - 6}$ & 15.26 & 14.886 \\
Linolenic acid C 18:3 $\boldsymbol{\omega} 3$ & 25.93 & 15.068 \\
\hline
\end{tabular}

In fact, Linolenic acid was the primary unsaturated fatty acids in date seeds with concentration $15.068 \%$, it was followed by Linoleic acid $(14.886 \%)$, Oleic acid $(14.035 \%)$, Heptadecenoic acid $(12.152 \%)$ and Hexadecenoic acid $(10.619 \%)$, respectively. Our results confirmed that there were differences in the amount of each saturated and unsaturated fatty acids in different varieties. According to Akbari et al. (2012) they analyzed three varieties of date seeds and revealed that Oleic acid was the primary fatty acid of all three varieties with concentrations of $37.6 \%, 31.5 \%$, and $31.8 \%$ of total fatty acids, respectively. It was followed by lauric $(25.68,30.51$ and $30.82 \%)$, myristic (13.28, 16.77 and $16.93 \%)$, palmitic (11.90, 13.08 and 13.11\%), linoleic (6.93, 4.41 and 4.46\%), stearic acid $(2.34,1.85$ and $1.87 \%)$ and trace amounts of the other fatty acids like undecylic, capric, nonanoic (pelargonic) and caprylic acids. Despite the difference in the amount of each fatty acid in all three 
varieties, their results indicated that there is no significant relationship between levels of fatty acids in three varieties.

\subsection{Biological evaluation}

The mean value of rats body weight gain (BWG), their feed intake (FI) and feed efficiency ratio (FER) were summarized in Table (5). Data presented could be observed that there was a significant decrease $(\mathrm{p}<0.05)$ in $\mathrm{BWG} \%$ for control positive group, as compared with healthy control group. BWG of all treated groups with DPP at various levels $(5 \%, 10 \% \& 15 \%)$ with SLP at $0.7 \%$ which used in fortification of diet recorded significant increase $(\mathrm{P}<0.05)$, in comparison with control positive group, this is may be due to the good nutritional value of feeding with SLP and DPP. These results are in harmony, with those obtained by Sumon et al. (2008). However, results in the same table indicated that diet fortified with DPP at $10 \%$ and $15 \%$ with $0.7 \%$ SLP consumption is associated with improved nutrient intakes and body weight and possibly reducing the risk of metabolic syndrome compared with positive control group. Confirmed by Misra et al. (2011) that Stevia leaves assist with weight control and weight loss by restricting or controlling calorie intake in the diet. Also, ingestion of steviol in high doses showed a reduction in body weight as experimented in rats.

Data in the same Table (5) noticed that there were significant differences in diet average daily feed intake between healthy group fed basal diet and diabetic group. The mean value of feed intake was less in positive group than in the group fed on healthy diet; the values were $(12.69 \pm 1.52 \mathrm{vs}$ $14.59 \pm 0.83 \mathrm{~g} /$ day) for each rat. Amount of feed intake values were higher in all treated groups $(\mathrm{P}<0.05)$ than the control positive group. In fact, feeding on diet fortified with DPP at various levels with $0.7 \%$ SLP improved feed intake of rats. Moreover, these results coincided with those obtained by Gupta et al. (2013) they found that the negative group fed on normal diet gave the highest body weight gain, and consumed the highest amount of their diet which reflected on their weight, while the diabetic group consumed the lowest level of their diet which gave the rats with the lowest body weight gain. Moreover, the feed efficiency ratio of all diabetic groups fed on basal diet with DPP with $0.7 \%$ recorded significant increased $(\mathrm{P}<0.05)$, as compared to control positive group. These results coincided with those obtained by Prabu \& Natarajan, (2013).

Table 5: Effect of diet with Stevial and date pits powder on feed intake, body weight gain \% \& Feed efficiency ratio of diabetic rats

\begin{tabular}{lccc}
\hline \multicolumn{1}{c}{ Parameters. } & $\begin{array}{c}\text { Body Weight Gain } \\
\text { (BWG) }\end{array}$ & $\begin{array}{c}\text { Feed Intake } \\
\text { (FI/g/day) }\end{array}$ & $\begin{array}{c}\text { Feed Efficiency } \\
\text { Ratio (FER) }\end{array}$ \\
\hline Control negative (B-) & $43.26^{\mathrm{a}} \pm 0.03$ & $14.59^{\mathrm{a}} \pm 0.83$ & $0.88^{\mathrm{a}} \pm 0.013$ \\
Control positive (B+) & $36.03^{\mathrm{d}} \pm 0.05$ & $12.69^{\mathrm{c}} \pm 1.52$ & $0.84^{\mathrm{d}} \pm 0.014$ \\
Control (+) + 5\% DPP + 0.7\% Slp & $40.22^{\mathrm{c}} \pm 0.07$ & $13.89^{\mathrm{b}} \pm 0.64$ & $0.87^{\mathrm{b}_{ \pm} \pm 0.11}$ \\
Control (+)+ 10\% DPP + 0.7\% Slp & $41.91^{\mathrm{b}} \pm 0.09$ & $14.47^{\mathrm{a}} \pm 0.43$ & $0.86^{\mathrm{bc}_{ \pm} \pm 0.17}$ \\
Control (+)+ 15\% DPP + 0.7\% Slp & $41.68^{\mathrm{b}} \pm 0.04$ & $14.38^{\mathrm{ab}} \pm 0.27$ & $0.86^{\mathrm{bc}} \pm 0.15$ \\
\hline
\end{tabular}

Values in each column which have different letters are significantly different $(\mathrm{p} \leq 0.05)$.

\subsection{Biochemical analysis of serum}

Data presented in Table (6) illustrated the effect of different levels of all treated groups with DPP and $0.7 \%$ SLP on concentrations of glucose, insulin and HbAlc of diabetic rats. Initial serum glucose $(\mathrm{mg} / \mathrm{dl})$ and HbAlc $(\%)$ levels showed significant decrease $(\mathrm{P}<0.05)$ in the control negative group (healthy rats), with increased in insulin $(\mathrm{U} / \mathrm{ml})$ secretion as compared to other groups. While, the serum glucose and $\mathrm{HbAlc}$ levels were increased as expected in alloxan injected rats to reach $154.49 \mathrm{mg} / \mathrm{dl}$ and $18.77 \%$, since alloxan causes a massive reduction in insulin $9.04 \mathrm{U} / \mathrm{ml}$, release by the destruction of the $\beta$-cells of the islets of Langerhans and inducing hyperglycemia, as reported by Prabu \& Natarajan, (2013) and Halaby et al. (2014), showed that HbAlc concentration is proportionately increased in diabetic patients with ambient hyperglycemic and reflects the extent as well as management of diabetic condition.

Feeding diabetic groups with DPP and SLP, which used in fortification of diet after eight weeks, resulted in a significant reduction in the blood glucose levels. $(\mathrm{P}<0.05)$ reached $(113.23 \pm$ $2.31 ; 98.60 \pm 4.02 \& 75.73 \pm 1.32 \mathrm{mg} / \mathrm{dl})$ respectively, compared to the positive control group $(154.49$ 
$\pm 3.21 \mathrm{mg} / \mathrm{dl})$. At the same time, the levels of HbAlc decreased to $(17.47 \pm 2.51 ; 16.53 \pm 3.41 \&$ $14.81 \pm 3.28 \%$ ) respectively, these results are in harmony with those Misra et al. (2011) and Shivanna et al. (2013), they studied the effects of Stevia and Stevia polyphenols on diabetes showing a reduction of blood glucose, and an increase in glucose tolerance and insulin sensitivity.

Insulin reached to $(15.40 \pm 4.02 ; 16.62 \pm 4.05 \& 17.86 \pm 3.07 \mathrm{U} / \mathrm{ml})$ after feeding on the diet fortified with DPP at various levels $5 \% ; 10 \% \& 15 \%$ with $0.7 \%$ SLP, could be due to the increased pancreatic secretion from existing $\beta$-cells. It is well documented that adherence to a healthy diet can improve glycemic control, which may reduce glycosylated hemoglobin (HbA1c) levels noted by Prabu \& Natarajan, (2013) confirmed by Mogra \& Dashora, (2009) and Gutierrez, (2013) that Stevia has been used for the treatment of diabetes mellitus, along with other disease states such as cancer, hypertension, fatigue and depression. It has been found to be non toxic, non addictive, non mutagenic, non teratogenic and is devoid of genotoxic effect.

Table 6: Effect of diet with Stevia and date pits powder on glucose, insulin and $\mathrm{HbA}_{1} \mathrm{C}$ of diabetic rats

\begin{tabular}{llll}
\hline \multicolumn{1}{c}{ Parameters } & $\begin{array}{l}\text { Glucose } \\
\text { Groups }\end{array}$ & $\begin{array}{l}\text { Insulin } \\
\text { G/dl) }\end{array}$ & $\begin{array}{l}\text { HbA1c } \\
\mathbf{W}\end{array}$ \\
Control negative (B-) & $67.04^{\mathrm{f}} \pm 2.41$ & $19.31^{\mathrm{a}} \pm 3.02$ & $12.65^{\mathrm{f}} \pm 3.16$ \\
Control positive (B+) & $154.49^{\mathrm{a}} \pm 3.21$ & $9.04^{\mathrm{e}} \pm 3.63$ & $18.77^{\mathrm{a}} \pm 3.26$ \\
Control (+) + 5\% DPP + 0.7\% Slp & $113.23^{\mathrm{b}} \pm 2.31$ & $15.40^{\mathrm{d}} \pm 4.02$ & $17.47^{\mathrm{b}} \pm 2.51$ \\
Control (+)+ 10\% DPP + 0.7\% Slp & $98.60^{\mathrm{c}} \pm 4.02$ & $16.62^{\mathrm{c}} \pm 4.05$ & $16.53^{\mathrm{c}} \pm 3.41$ \\
Control (+)+ 15\% DPP + 0.7\% Slp & $75.73^{\mathrm{d}} \pm 1.32$ & $17.86^{\mathrm{b}} \pm 3.07$ & $14.81^{\mathrm{d}} \pm 3.28$ \\
\hline
\end{tabular}

All results are expressed as mean $\pm \mathrm{SD}$.

Values in each column which have different letters are significantly different $(p<0.05)$.

The effect of fortification of the diet with different levels of Date pits powder with Stevia on concentrations of the lipid profile presented in (Table 7). It could be noticed that the positive control group fed on basal diet has shown a significant increase in the mean values of TC, TG, LDL-C and VLDL-C $(102.58 \pm 5.92 ; 85.62 \pm 2.51 ; 51.16 \pm 2.78 \& 19.01 \pm 0.53 \mathrm{mg} / \mathrm{dl})$ respectively, compared with the control negative group fed on the basal diet $(98.04 \pm 3.12 ; 55.14 \pm 2.34 ; 42.20 \pm 1.98 \&$ $12.90 \pm 0.83 \mathrm{mg} / \mathrm{dl}$ ) respectively, these findings are in agreement with Mishra, (2010).

Table 7: Effect of diet with Stevia and Date pits powder on serum Cholesterol, Triglycerides, Highdensity, low and very low density lipoprotein Cholesterol in diabetic rats

\begin{tabular}{llllll}
\hline \multirow{2}{*}{ Groups } & \multicolumn{5}{c}{ mg/dl } \\
\hline Control negative (B-) & $98.04^{\mathrm{c}} \pm 3.12$ & $55.14^{\mathrm{f}} \pm 2.34$ & $53.25^{\mathrm{a}} \pm 1.82$ & $42.20^{\mathrm{d}} \pm 1.98$ & $12.90^{\mathrm{e}} \pm 0.83$ \\
Control positive (B+) & $102.58^{\mathrm{a}} \pm 2.94$ & $85.62^{\mathrm{a}} \pm 2.51$ & $44.36^{\mathrm{d}} \pm 3.09$ & $51.16^{\mathrm{a}} \pm 2.78$ & $19.01^{\mathrm{a}} \pm 0.53$ \\
Control (+) + 5\% DPP + 0.7\% Slp & $98.28^{\mathrm{c}} \pm 2.31$ & $74.18^{\mathrm{b}} \pm 2.04$ & $49.32^{\mathrm{c}} \pm 2.47$ & $48.18^{\mathrm{b}} \pm 2.34$ & $15.65^{\mathrm{b}} \pm 0.67$ \\
Control (+)+ 10\% DPP + 0.7\% SIp & $99.76^{\mathrm{b}} \pm 3.24$ & $67.66^{\mathrm{c}} \pm 4.14$ & $50.37^{\mathrm{b}} \pm 1.28$ & $45.62^{\mathrm{c}} \pm 3.08$ & $14.47^{\mathrm{c}} \pm 0.89$ \\
Control (+)+ 15\% DPP + 0.7\% Slp & $93.96^{\mathrm{d}} \pm 2.05$ & $59.28^{\mathrm{d}} \pm 2.30$ & $53.31^{\mathrm{a}} \pm 1.38$ & $43.82^{\mathrm{c}} \pm 1.19$ & $13.64^{\mathrm{d}} \pm 0.35$ \\
\hline
\end{tabular}

Diabetic rats which were treated with the diet fortified at $0.7 \%$ Stevia and $10 \%$ Date pits powder, or fed on basal diet fortified with mixed of $0.7 \%$ Stevia and $15 \%$ Date pits powder, had lower mean values of lipid profile compared with the positive control group. The reduction of lipid profile associated with an increase of HDL-C in diabetic rats. This might be due to decrease of cholesterol absorption and biosynthesis and increase of faecal bile acid and cholesterol excretion. In fact, the best results for all treated groups was noticed in group fed on basal diet fortified with mixed from $10 \%$ and $15 \%$ DPP with $0.7 \%$ SLP compared with the control positive group. These findings are in agreement with Sharma et al. (2009) they showed the effect of consumption of Stevia extract on 20 selected hypercholesterolemic women, and found that consumption of $20 \mathrm{ml}$ extract in a glass of water (200 $\mathrm{ml}$ ) helps in the reduction of bad cholesterol such as triglyceride and low-density lipoprotein (LDL) with significant increase in good cholesterol that is high-density lipoprotein (HDL), and it was 
concluded that Stevia extract had a hypolipidaemic effect and it maintains cardiovascular health. The previous studies Gupta et al. (2013) proved that the clinical efficacy of Stevia leaves in reducing chronic hypertension by relaxing arteries and help prevent the build up of calcium on artery walls.

The effect of fortification the basal diet with the different levels of Date pits powder and Stevia on serum levels of both Aspartate Amine Transferase AST (U/L) and Alanine Amine Transferase $\operatorname{ALT}(\mathrm{U} / \mathrm{L})$ as useful indicator for liver functions in diabetic rats are presented in Table (8). It could be noticed that control positive group fed on basal diet showed a significant increase $(p<0.05)$ in the mean values of AST \& ALT (56.94 \pm 3.88 and $20.57 \pm 5.45 \mathrm{U} / \mathrm{L})$, respectively, compared with those of the healthy rats fed on the same type of diet $(24.41 \pm 3.45$ and $8.78 \pm 1.35 \mathrm{U} / \mathrm{L})$, respectively.

The liver dysfunction associated with diabetes was reported by Reda, (2006) revealed that, serum AST and ALT levels increased in diabetic rats, compared with negative control rats. Also, these results of the present study agree with Hadrami \& Al-Khayri, (2012) who published that with improving diabetic diet may help to prevent a variety of diseases. In addition, individuals with type 2 diabetes have a higher incidence of liver function test abnormalities than individuals who do not have diabetes. Mild chronic elevations of transaminases often reflect underlying insulin resistance (Salih, 2013). From these results, there was significant difference $(\mathrm{P}<0.05)$ between positive control group and other groups fed on diet fortified with different levels of DPP with Stevia caused a significant reduction in the mean values of serum AST \& ALT in diabetic rats, as compared to the positive control groups.

Table 8: Effect of diet with Stevia and date pits powder on Liver function of diabetic rats

\begin{tabular}{|c|c|c|c|}
\hline \multirow[b]{2}{*}{ Groups } & \multirow[t]{2}{*}{ Parameters } & \multicolumn{2}{|c|}{$(\mathrm{u} / \mathbf{l})$} \\
\hline & & AST & ALT \\
\hline Control negative (B-) & & $24.41^{\mathrm{f}} \pm 3.45$ & $8.78^{\mathrm{f}} \pm 1.35$ \\
\hline Control positive $(\mathrm{B}+)$ & & $56.94^{\mathrm{a}} \pm 3.88$ & $20.57^{\mathrm{a}} \pm 5.45$ \\
\hline Control $(+)+5 \%$ DPP + $0.7 \%$ Slp & & $43.26^{\mathrm{b}} \pm 4.37$ & $12.75^{\mathrm{bc}} \pm 1.86$ \\
\hline Control $(+)+10 \%$ DPP $+0.7 \%$ SIp & & $37.34^{\mathrm{c}} \pm 4.88$ & $11.57^{\mathrm{c}} \pm 1.61$ \\
\hline Control (+)+ $15 \%$ DPP $+0.7 \%$ SIp & & $28.26^{\mathrm{d}} \pm 4.21$ & $10.29^{\mathrm{d}} \pm 1.58$ \\
\hline
\end{tabular}

All results are expressed as mean \pm SD.

Values in each column which have different letters are significantly different $(p<0.05)$.

Kidneys remove metabolic wastes such as uric acid, urea nitrogen and creatinine, so optimum chemical composition of body fluids is maintained. The concentrations of the metabolites increase in blood during renal diseases or renal damage may due to high activities of xanthine oxidase, lipid peroxidation, and increased triacylglycerol and cholesterol levels (Barakat \& Mahmoud, 2011).

The effect of different levels of Date pits powder with Stevia, which used in fortified diet on kidney functions of diabetic rats is presented in Table (9). Results showed that, serum uric acid, urea nitrogen and creatinine of diabetic groups increased significantly $(\mathrm{p}<0.05)$, as compared to the negative control groups $(3.46 \pm 0.13 ; 90.44 \pm 7.84 \& 1.08 \pm 0.09$ vs $1.41 \pm 0.14 ; 62.78 \pm 6.83 \& 0.75$ $\pm 0.08 \mathrm{mg} / \mathrm{dl}$ respectively). Renal dysfunction due to oxidative damage associated with diabetes, as stated by Jachec et al. (2002), as an important reason as well.

Table 9: Effect of diet with Stevia and date pits powder on Kidney function of diabetic rats

\begin{tabular}{|c|c|c|c|}
\hline \multirow[t]{2}{*}{ Parameters } & \multicolumn{3}{|c|}{$\mathrm{mg} / \mathrm{dl}$} \\
\hline & Uric acid & Urea nitrogen & Creatinine \\
\hline Control negative (B-) & $1.41^{\mathrm{e}} \pm 0.14$ & $62.78^{\mathrm{e}} \pm 6.83$ & $0.75^{\mathrm{e}} \pm 0.08$ \\
\hline Control positive $(\mathrm{B}+)$ & $3.46^{\mathrm{a}} \pm 0.13$ & $90.44^{\mathrm{a}} \pm 7.84$ & $1.08^{\mathrm{a}} \pm 0.09$ \\
\hline Control $(+)+5 \%$ DPP $+0.7 \%$ Slp & $2.56^{\mathrm{b}} \pm 0.23$ & $80.07^{b} \pm 2.97$ & $0.94^{\mathrm{b}} \pm 0.12$ \\
\hline Control $(+)+10 \%$ DPP $+0.7 \%$ Slp & $1.79^{c} \pm 0.13$ & $73.29^{c} \pm 3.17$ & $0.88^{\mathrm{c}} \pm 0.03$ \\
\hline Control $(+)+15 \%$ DPP $+0.7 \%$ Slp & $1.59^{\mathrm{d}} \pm 0.17$ & $71.21^{\mathrm{cd}} \pm 2.02$ & $0.81^{\mathrm{d}} \pm 0.05$ \\
\hline
\end{tabular}

All results are expressed as mean \pm SD.

Values in each column which have different letters are significantly different $(p<0.05)$. 
Diabetes is among the leading causes of kidney failure. Ten to twenty percent of people with diabetes die of kidney failure Singh et al. (2012) that confirmed previously by Shebl et al. (2013) who declared that the chronic elevation of plasma glucose causes many of the major complications of diabetes including nephropathy, retinopathy, neuropathy, macro- and micro vascular damages. Moreover, results indicated that, the treated groups fed on fortified diet with DPP and SLP induced significant decrease $(\mathrm{p}<0.05)$ in the studied parameters, as compared to the positive control group. The highly significant reduction of all parameters observed in the diabetic group fed on basal diet containing the $15 \%$ DPP with $0.7 \%$ SLP compared with control positive group.

\section{Conclusion}

Results revealed that Date pits powder with Stevia leaves had positive and encouraging effect on decreasing the risk of diabetic disease and lipid profile. No adverse effect was observed on the health status of the rats and it can thus be concluded that the SLP and DPP may be used as dietary supplement or as food additive due to these leaves and seeds powder intervention is effective in lowering the elevated levels of serum cholesterol, triglyceride, low density lipoprotein and very low density lipoprotein levels and increasing the HDL levels. Researchers need to work more on DPP with SLP for clinical evidences and demonstration of metabolic pathways regarding benefits to explore its full potential.

\section{Recommendations}

- Educational programs should be designed to inform the public about the effect of Date pits powder with Stevia leaves on decreasing the risk of diabetic disease.

- The study may encourage pharmacologists, plant chemists, biochemists and molecular biologists to combine their efforts in a search for natural agents that can limit with better therapeutic management of diabetic diseases.

\section{References}

A.O.A.C. 2005. Association of Official Analytical Chemists. Official Methods of Analytical Methods AOAC, 18th Edition, AOAC, Gaithersburg, Maryland, USA.

A.O.A.C. 2007. Official Methods of Analysis of the Association of official Analytical chemists. 18th Ed.Gaithersburg, Maryland, U.S.A.

Abd El-Latif, B.M., 1990. Improvement of some bakery products thesis. Ph.D. F. Tech. Agric. Moshtohor, Zagazig Univ.

Akbari, M., R. Razavizadeh, G. Mohebbi, and A. Barmak, 2012. Oil characteristics and fatty acid profile of seeds from three varieties of date palm (Phoenix dactylifera) cultivars in BushehrIran. African Journal of Biotechnology, 11 (57): 12088-12093.

Allain, C., L. Poon, C. Chan, and W. Richmond, 1974. Enzymatic determination of total serum cholesterol. Clinical Chemistry, 20: 470-475.

Amany, M., M. Shaker, and A. Abeer, 2012. Antioxidant activities of date pits in a model meat system. International Food Research Journal, 19 (1): 223-227

American Diabetes Association 2018. Classification and Diagnosis of Diabetes: Standards of Medical Care in Diabetesd 2018. Diabetes Care Volume 41, Supplement 1, January.

Ardekani, M., M. Khanavi, M. Hajimahmoodi, M. Jahangiri, and A. Hadjiakhoondi, 2010. Comparison of antioxidant activity and total phenol contents of some date seed varieties from Iran. Iranian Journal of Pharmaceutical Research, 9: 141-146.

Armitage, P. and G. Berry, 1987. Statistical methods in medical research. Distributors, USA, Year Book Medical Publishers.

Barakat, L. and R. Mahmoud, 2011. The antiatherogenic, renal protective and immunomodulatory effects of purslane, pumpkin and flax seeds on hypercholesterolemic rats. North American Journal of Medical Sciences, 3 (9): 351-357.

Bartel, H., M. Bohemer, and C. Heirli, 1972. Colorimetric kinetic method of creatinine. Clin. Chem. Acta., 37: 193.

Baynest, H.W., 2015. Classification, Pathophysiology, Diagnosis and Management of Diabetes Mellitus. Baynes J Diabetes and Metabolism, 6(5):1-9. 
Bouaziz, M., W. Amara, H. Attia, C. Blecker, and S. Besbes, 2010. Effect of the addition of defatted date seeds on wheat dough performance and bread quality. Journal of Texture Studies, 41: $511-531$.

Burgi, W., M. Briner, N. Franken, and A. Kessler, 1988. One step sandwich enzyme immuno assay for insulin using monoclonal antibodies. Clin. Biochem., 21: 311-314.

Campos, M., E. Martín, A. Basto, D. Amaro, M. Olmedo, Y. Ordoñez, and D. Ancona, 2014. Comparison of Chemical and Functional Properties of Stevia rebaudiana (Bertoni) Varieties Cultivated in Mexican Southeast. American Journal of Plant Sciences, 5: 286-293.

Chahal, D., M. Moo-Young, and G. Dhillon, 1979. Bioconversion of wheat straw and wheat straw components into single- cell protein. Canadian of Microbiology, 25:793-797.

Chapman, D., R. Gastilla, and J. Campbell, 1959. Evaluation of protein in food. Method for the determination of protein efficiency ratio. Can. J. Biochem. Physiol., 37: 679 - 686.

El-Porai, E., A. Salama, A. Sharaf, A. Hegazy, and M. Gadallah, 2013. Effect of different milling processes on Egyptian wheat flour properties and pan bread quality. Annals of Agricultural Science, 58 (1): 51-59.

Fossati, P. and L. Prencipe, 1982. Serum Triglycerides Determined Colorimetrically with an Enzyme that Produces Hydrogen Peroxide. Clinical Chemistry, 28: 2077-2080.

Fossati, P., L. Prencipe, and G. Berti, 1980. Use of 3, 5-dichloro-2-hydroxybenzene-sulfonic acid/4aminophenazone chromogenic system in direct enzymatic assay of uric acid in serum and urine. Clinical chemistry, 26: 227-231.

Friedewald, W., R. Levy, and D. Fredrickson, 1972. Estimation of the concentration of low-density lipoprotein cholesterol without the use of the preparative ultracentrifuge. Clini. Chemi., 18: 499-502.

Gasmalla, M., R. Yang, A. Musa, X. Hua, and W. Zhang, 2014. "Physico-chemical Assessment and Rebauidioside A. Productively of Natural Sweeteners (Stevia Rebaudiana Bertoni).” Journal of Food and Nutrition Research, 2 (5): 209-214.

Geuns, J., P. Augustijns, R. Mols, J. Buyse, and B. Driessen, 2003. Metabolism of stevioside in pigs and intestinal absorption characteristics of stevioside, rebaudioside A and steviol. Food Chem. Toxicol. 41:1599-607

Gupta, E., S. Purwar, S. Sundaram, and G. Rai, 2013. Nutritional and therapeutic values of Stevia rebaudiana: A review. Journal of Medicinal Plants Research, 7 (46): 3343-3353.

Gutierrez, S.A., 2013. Stevia and Long Term Glycemic Control in Type 2 Diabetic Patients. Nutritional Sciences, Department/Field of Concentration, 6-10.

Hadrami, A. and J. Al-Khayri, 2012. Socioeconomic and traditional importance of date palm. Emir. J. Food Agric., 24 (5): 371-385.

Halaby, M.S., M.H. Farag, and A.H. Gerges, 2014. Potential Effect of Date Pits Fortified Bread on Diabetic Rats. International Journal of Nutrition and Food Sciences. 3 (2): 49-59.

Hegested, D., R. Mills, C. Elvehijem, and F. Hart, 1941. Choline in the nutrition of check.

ISO 5508 (1990).and ISO 5509 (2000).

Jachec, W., A. Tomasik, R. Tarnawski, and E. Chwalinska, 2002. Evidence of oxidative stress in the renal cortex of diabetic rats: favorable effect of vitamin E. Scand. J.Clin. Lab. Invest., 62 (1): 81-88.

Jitendra, M., S. Monika, S. Ratan, G. Priyanka, S. Priyanka, and D. Kiran, 2012. Micropropagation of an Anti diabetic Plant - Stevia rebaudiana Bertoni, (Natural Sweetener) in Hadoti Region of South-East Rajasthan, India. ISCA Journal of Biological Sciences Vol. 1 (3): 37-42.

Journal of chromatography A., 1999. 721:247-259.

Journal of chromatography B., 2006. 830:41-46.

Kanapka, J. and I. Kleinberg, 1983. Catabolism of Arginine by the Mixed Bacteria in human salivary sediment under conditions of low and High glucose concentration, Arch. Oral. Biol., 28: $1007-1015$.

Kolb, N., J. Herrera, D. Ferreyra, and R. Uliana, 2001. Analysis of sweet diterpene glycosides from Stevia rebaudiana: Improved HPLC Method. J. Agric. Food Chem., 49 (10): 4538-4541

Lopes, M., S. Stone, S. Ellis, and J. Collwell, 1977. Cholesterol determined in high denisty lipoprotein separated by three different methods. Clin. Chem., 23 (5): 882. 
Mishra, P., R. Singh, U. Kumar, and V. Prakash, 2010. Stevia rebaudiana - A magical sweetener. Global. J. Biotech. Biochem., 5: 62-74.

Misra, H., M. Soni, N. Silawat, D. Mehta, B. Mehta, and D. Jain, 2011. Antidiabetic activity of medium-polar extract from the leaves of Stevia rebaudiana Bert. (Bertoni) on alloxan-induced diabetic rats. J. Pharm. Bioall. Sci., 3: 242-248.

Mobarak, S.A., 2009. Antioxidant properties of date palm (Phoenix dactylifera L.) cultivars. Ph.D. Colorado State University.

Mogra, R. and V. Dashora, 2009. Exploring the Use of Stevia rebaudiana as a Sweetener in Comparison with Other Sweeteners. Journal of Human Ecology, 25 (2): 117-120.

Mondaca, R., A. Gálvez, L. Bravo, and K. Ah-Hen, 2012. Stevia rebaudiana Bertoni, source of a high-potency natural sweetener: A comprehensive review on the biochemical, nutritional and functional aspects. Food Chemistry, 132: 1121-1132.

Najafi, M., 2011. Date Seeds: A Novel and Inexpensive Source of Dietary Fiber. International Conference on Food Engineering and Biotechnology, 323- 326.

Nandhagopal, K., M. Kanniyakumari, J. Anbu, and V. Velpandian, 2013. Antidiabetic activity of karchure chooranam on alloxan induced diabetic rats. Int J. Pharm. Bio. Sci., 4 (1): $434-439$.

Patton, C. and S. Crouch, 1977. Spectrophotometric and kinetics investigation of the Berthelot reaction for the determination of ammonia: Analytical Chemistry, 49: 464-469.

Prabu, K. and E. Natarajan, 2013. Antihyperglycemic effect of chitosan of podophthalmus vigil in streptozotocin induced diabetic rats. prabu and natarajan, ijpsr., 4 (1): 352-359

Punthakee, Z., R. Goldenberg, and P. Katz, 2018. Definition, Classification and Diagnosis of Diabetes, Prediabetes and Metabolic Syndrome. Canadian Journal of Diabetes, 42: 10-15.

Reda, M.M., 2006. The effect of barley and barley fortified bread on diabetic rats. M.Sc. Thesis, Of Home Economics. Helwan Univ. Egypt.

Reeves, P., F. Nielsen, and G. Fahmy, 1993. Report of The American Institute of Nutrition adhoc wriling committee on the reformulation of the AIN - 76 A Rodent diet. J. Nutr., $123: 1939$ 1951.

Reitman, S. and S. Frankel, 1957. Colorimetric method for the determination of serum glutamic oxalacetic and glutamic pyruvic transaminases. Amer. J. Clin. Pathol., 28: 56-63.

Sabah, A., A. Jassim, and M. Naji, 2010. In vitro evaluation of the antiviral activity of an extract of Date Palm (Phoenix dactylifera L.) pits on a Pseudomonas Phage. Evid Based Complement Alternat Med. March; 7(1): 57-62.

Salih, D.H., 2013. Study of liver function tests and renal function tests in diabetic type II patients. IOSR Journal of Applied Chemistry (IOSR-JAC). 3 (3): 42-44.

Sharma, N., R. Mogra, and B. Upadhyay, 2009. Effect of Stevia Extract Intervention on Lipid Profile. Ethno-Med, 3(2): 137-140.

Shebl, R., S. Samaha, S. Mohammed, N. Gabr, and A. Al-Gendy, 2013. Evaluation of Simvastatin and/or Ezetimibe treatment on some diabetic complications in Streptozotocin induced diabetes in rats. Journal of American Science, 9(4).

Shehzad, M., H. Rasheed, S. Naqvi, J. Al-Khayri, J. Lorenzo, M. Alaghbari, M. Manzoor, and R. Aadil, 2021. Review Therapeutic Potential of Date Palm against Human Infertility Metabolites, 11 (408): 2-19.

Shivanna, N., M. Naika, F. Khanum, and V. Kaul, 2013. Antioxidant, anti-diabetic and renal protective properties of Stevia rebaudiana. J. Diabetes Complicat., 27: 103-113.

Singh, S., V. Garg, D. Yadav, M.N. Beg, and N. Sharma, 2012. In vitro antioxidative and antibacterial activities of various parts of Stevia rebaudiana (Bertoni). Int. J. Pharm. Pharm. Sci., 4: 468473.

Singh, K., M. Chauhan, S. Yadav, and V. Kumar, 2021. Stevia (Stevia rebaudiana): A Natural Healer for Diabetes, Heart Diseases and Other Metabolic Disorders. Vivechan International Journal of Research. 10 (1). ISSN No. 0976-8211.

Sudhakar, N. and T. Pattabiraman, 1981. A new colorimetric method for the estimation of glycosylated haemoglobin. Clin. Chim. Acta., 109: 267-274.

Sumon, M., M. Mostofa, M. Jahan, M. Kayesh, and M. Haque, 2008. Comparative efficacy of powdered form of stevia (Stevia rebaudiana bertoni) leaves and glimerpiride in induced diabetic rats. bangladesh journal of veterinary medicine, 6(2): 211-215. 
Tanaka, M., C. Robinson, and M. Moo-Young, 1985. Chemical and enzymic pretreatment of corn stover to produce soluble fermentation substrates. Biotechnology and Bioengineering. 27: 362-368.

Trinder, P., 1959. Determination of blood glucose using 4-amino phenazone. J. Clin. Path., 22: 246.

Walid, A. and J. Richard, 2003. Fatty acid content of the seeds from 14 varieties of date palm Phoenix dactylifera L. International Journal of Food Sci. Technol., 38:709-712.

Xing, R., X. He, S. Liu, H. Yu, Y. Qin, X. Chen, K. Li, R. Li, and P. Li, 2015. Antidiabetic Activity of Differently Regioselective Chitosan Sulfates in Alloxan- Induced Diabetic Rats. Mar. Drugs, 13: 3072-3090.

Yadav, S. and P. Guleria, 2012. Steviol glycosides from Stevia: biosynthesis pathway review and their application in foods and medicine. Critical reviews in food science and nutrition, 52 (11): 988-998.

Zheng, Y., S. Ley, and F. Hu, 2018. Global aetiology and epidemiology of type 2 diabetes mellitus and its complications. Nat. Rev. Endocrinol., 14 (2): 88-98. 